\title{
RESEARCH
}

Open Access

\section{Uptake and predictors of direct-acting antiviral treatment for hepatitis $C$ among people receiving opioid agonist therapy in Sweden and Norway: a drug utilization study from 2014 to 2017}

\author{
Christer F. Aas ${ }^{1,2,3^{*}}$ D, Jørn Henrik Vold ${ }^{1,2}$, Svetlana Skurtveit ${ }^{4}$, Ingvild Odsbu ${ }^{5}$, Fatemeh Chalabianloo 1,2, \\ Aaron G. Lim ${ }^{6}$, Kjell Arne Johansson ${ }^{1,2}$ and Lars Thore Fadnes ${ }^{1,2}$
}

\begin{abstract}
Background: Treatment with direct-acting antiviral agents (DAAs) offers an opportunity to eliminate hepatitis C virus (HCV) endemic among people who inject drugs (PWID) and people enrolled in opioid agonist therapy (OAT) programs. The objective of this study was to estimate and to compare HCV treatment uptake after the introduction of DAAs among patients receiving OAT in Sweden and Norway. We also aimed to evaluate predictors of DAAs treatment among OAT patients in both countries.

Methods: This observational study was conducted with data from The Swedish Prescribed Drug Register and The Norwegian Prescription Database. We studied dispensed medications to calculate HCV treatment among OAT patients from 2014 to 2017 in Sweden and Norway. HCV prevalence was estimated from primary and secondary sources. Dispensations of medicines from different therapeutic areas, which served as proxy for co-morbidities in 2017, were conditionally adjusted for age, gender, and OAT medications. Logistic regression was used to evaluate these parameters.
\end{abstract}

Results: In total 3529 individuals were identified with dispensed OAT in the Swedish cohort and 7739 individuals in the Norwegian cohort. HCV treatment was utilized by 407 persons in Sweden and 920 in Norway during the study period. Annual HCV and DAA treatment uptake increased in both countries. The estimated cumulative HCV treatment uptake at the end of 2017 was 31\% in Norway and 28\% in Sweden. DAA treatment was associated with increased age (aOR 1.8; 95\% Cl 1.0-3.2) and the dispensation of drugs used for diabetes (aOR 3.2; 95\% Cl 1.8-5.7) in Sweden. In Norway, lipid modifying agents and antibacterials were associated with decreased odds $(\mathrm{aOR} 0.4 ; 95 \% \mathrm{Cl}$ $0.2-0.9$, aOR 0.8; 95\%Cl 0.6-1.0).

(Continued on next page)

* Correspondence: christer.frode.aas@helse-bergen.no

'Department of Addiction Medicine, Haukeland University Hospital, Bergen, Norway

2Department of Global Public Health and Primary Care, University of Bergen, Bergen, Norway

Full list of author information is available at the end of the article

C The Author(s). 2020 Open Access This article is licensed under a Creative Commons Attribution 4.0 International License, which permits use, sharing, adaptation, distribution and reproduction in any medium or format, as long as you give appropriate credit to the original author(s) and the source, provide a link to the Creative Commons licence, and indicate if changes were made. The images or other third party material in this article are included in the article's Creative Commons licence, unless indicated otherwise in a credit line to the material. If material is not included in the article's Creative Commons licence and your intended use is not permitted by statutory regulation or exceeds the permitted use, you will need to obtain permission directly from the copyright holder. To view a copy of this licence, visit http://creativecommons.org/licenses/by/4.0/. The Creative Commons Public Domain Dedication waiver (http://creativecommons.org/publicdomain/zero/1.0/) applies to the data made available in this article, unless otherwise stated in a credit line to the data. 


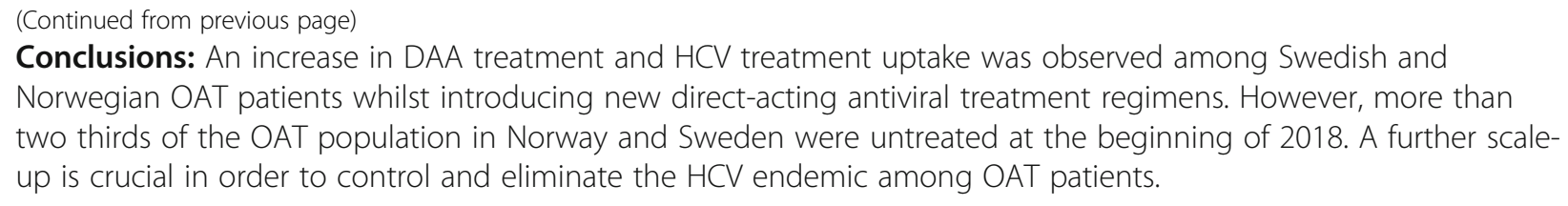

Keywords: Hepatitis C, Chronic hepatitis C, Treatment uptake, Direct-acting antivirals, Opioid substitution treatment

\section{Background}

Treatment of chronic hepatitis $\mathrm{C}$ virus $(\mathrm{HCV})$ infection has been subject to vivid changes in the last few years with the introduction of direct-acting antiviral agents (DAAs) [1]. The ambition of any antiviral treatment of $\mathrm{HCV}$ infection is elimination of the virus. In that sense, standard treatment prior to 2011 was a combination of pegylated interferon alpha and ribavirin, which saw a sustained virologic response (SVR) in approximately 50 to $56 \%$ of patients $[1,2]$. SVR is defined as absence of HCV RNA 12 weeks after end of treatment. However, since 2011 various DAAs have become readily available and should make interferon-based therapies almost obsolete. HCV policies including DAA offer countries an opportunity to eliminate HCV endemics, with less side effects, shorter treatment periods and improved adherence as compared to old interferon treatment. Combining two (or three) DAAs have led to a SVR of far beyond $90 \%$ also among patients who have been hard to treat in the past $[3,4]$.

The scale of the HCV endemic among people who inject drugs (PWID) is tragic and is a result of years of failing health policies for vulnerable populations. The HCV prevalence is around 50\%, or more, among PWIDs $[5,6]$, and around $50 \%$ among patients on opioid agonist therapy (OAT) [7]. It is estimated that HCV complications will continue to increase within the next few years [8]. DAA treatment has been offered as universal health coverage from 2017 and 2018 in Sweden and Norway, respectively $[9,10]$. It seems, however, that the increased accessibility has not benefitted active-PWIDs [11].

The coverage of preventive interventions and harm reduction services varies among PWIDs. Although the distribution of needle and syringe programs is relatively poor [12], opioid treatment programs such as OAT has higher coverage in many countries [13]. OAT has shown to reduce the risk of $\mathrm{HCV}$ acquisition [14], and despite ongoing illicit drug use, patients on OAT are achieving high SVR rates [15]. Hence, OAT programs may be a critical intervention for achieving large reductions in HCV transmissions. Several studies have shown that significant reductions in $\mathrm{HCV}$ prevalence can be achieved with an adequate increase in HCV treatment uptake [16-18]. Nevertheless, HCV treatment uptake has remained low $[19,20]$. In Norway, annual HCV treatment uptake among
OAT patients ranged from 1.3 to $2.6 \%$ in the period from 2004 to 2013 [20]. HCV treatment uptake, and in particular DAA treatment, among OAT patients in Sweden is unknown. Norway and Sweden share a basic cultural unity, have a comparable socioeconomic and political structure with similar health care systems that are based on the Nordic welfare model [21]. Taking into consideration the potential for $\mathrm{HCV}$ disease elimination by publicly funded DAA policies in these countries $[9,13]$ and the high HCV prevalence among the OAT population, it is essential to calculate the DAA treatment within an OAT delivery platform. Such estimates are important for countries aiming for $\mathrm{HCV}$ elimination or endemic control in the near future.

Therefore, this observational study aims to:

1) calculate HCV treatment annually and cumulatively after the introduction of DAAs among patients receiving OAT in Sweden from 2014 to 2017

2) compare DAA treatment between Sweden and Norway among patients receiving OAT from 2014 to 2017 and estimate the HCV treatment uptake

3) evaluate if various dispensed drugs (proxy for comorbidities), age, gender and OAT medication is associated with DAA treatment among OAT patients in Sweden and Norway in 2017

\section{Methods \\ Study design and data sources}

This is an observational study among patients on OAT in Sweden and Norway from 2014 to 2017. Data were extracted from The Swedish Prescribed Drug Register and The Norwegian Prescription Database. The registries cover the entire Norwegian and Swedish populations and record all drugs dispensed from pharmacies. All drugs are classified according to The Anatomical Therapeutic Chemical (ATC) classification system [22]. $\mathrm{HCV}$ prevalence data is not readily available for Norway and Sweden. Consequently, we employed primary and secondary sources to model HCV prevalence. Data from the INTRO-HCV study in Norway [23] was used in addition to published data on HCV prevalence among a large cohort of Swedish PWIDs [24]. See additional file 1 for a comprehensive description of methodology and data sources. 


\section{Study population and definitions}

The study population included all individuals aged 18 to 75 years who received OAT in Sweden and Norway. OAT was defined as being dispensed at least one defined daily dose (DDD) per day per calendar year of buprenorphine, methadone, buprenorphine-naloxone, or levomethadone by summarizing all annually dispensed OAT DDDs divided by 365.25 days.

Moreover, OAT medication per individual was noted as the last dispensation per calendar year. To avoid including other medical indications than OAT, we excluded methadone preparations on the basis of route of administration (injections and tablets), and introduced a dosage criteria in order to make sure that actual patients on OAT were captured. The dosage criteria was set at minimum one DDD daily throughout each calendar year as an inclusion criteria. The study populations were thus chosen annually for both countries and it was possible for an individual to be included in more than one calendar year. See additional file 2 for a flow chart. ATC/ DDDs according to 2017 [25] were used to quantify the dispensed OAT medications. A more detailed description of OAT and HCV treatment in Sweden and Norway is provided in additional file 3.

\section{Calculating HCV and DAA treatment and estimating treatment uptake}

HCV treatment was defined as being dispensed either one or more types of pegylated interferon alpha in combination with ribavirin, or one or more of the DAAs per calendar year during the study period (additional file 4). For each country, the annual HCV treatment rates were calculated by dividing the number of individuals with dispensed $\mathrm{HCV}$ treatment by the number of individuals on OAT. The cumulative HCV treatment frequency, which is the sum of successive years of treatment, was then calculated as the proportion of patients with dispensed $\mathrm{HCV}$ treatment at some point during the study period. Similarly, DAA treatment was calculated by dividing the number of OAT patients with at least one dispensation of DAA by the total number of OAT patients per year, which represents the annual prevalence of DAA use among OAT patients. Using primary and secondary sources, along with several assumptions, as described in detail in additional file 1, we derived a formula to estimate the chronic HCV prevalence in Sweden and Norway as follows;

\section{Expected Number of Chronic HCV}

$$
=\left((\mathbf{1}-\boldsymbol{\delta}) *\left[\boldsymbol{\phi} * \boldsymbol{\pi}_{\mathrm{PWID}}+(\mathbf{1}-\boldsymbol{\phi}) * \boldsymbol{\pi}_{\text {NonPWID }}\right] * \boldsymbol{N}\right)-\boldsymbol{\tau}
$$

where $N$ is the size of the study population, $\delta$ is the rate of spontaneous HCV clearance, $\phi$ is the proportion of OAT patients who are PWID, $\pi_{P W I D}$ and $\pi_{\text {NonPWID }}$ are the anti-HCV prevalence estimates among PWID and non-PWID, respectively, and $\tau$ is the number of $\mathrm{HCV}$ treatments given. Using the above formula, we calculate the expected number of chronic $\mathrm{HCV}$ infections in 2014-2017 for Norway and Sweden, with uncertainty in this quantity arising only from the uncertainty in spontaneous clearance. The chronic $\mathrm{HCV}$ prevalence was then calculated by dividing the expected number of chronic HCV infections by the total population size in that particular year and setting (i.e. Norway or Sweden). HCV treatment uptake was then estimated by dividing the HCV treatments in each year by the estimated number of chronic HCV infections in that same year, yielding a percentage of chronic $\mathrm{HCV}$ infections that were treated per year. The cumulative HCV treatment uptake was then calculated as the sum of $\mathrm{HCV}$ treatment uptake across years.

Potential predictors associated with DAA treatment uptake were determined a priori and included OAT medication (methadone/levomethadone vs. buprenorphine-based), age, gender and various dispensed drugs (yes vs. no) from different therapeutic areas that were used as proxies for comorbidities. All dispensations were recorded at the second ATC level (therapeutic subgroup), except for drugs affecting the nervous system.

\section{Statistical analyses}

All data analyses was conducted in STATA SE 16.0 (StataCorp, TX, USA). Descriptive data was presented as frequencies, percentages, and means, with corresponding 95\% confidence intervals where appropriate. Logistic regression was used to estimate whether DAA treatment uptake was associated with gender, age, OAT medication, and dispensations of other drugs in 2017. Statistical significance was set at the $p<0.05$ level.

\section{Data handling and ethical considerations}

All data were received pseudonymised from registry administrators and subsequently analyzed, therefore, no written consent was obtained from any of the individuals in the study. The study was approved by the Regional Ethical Review Committee in Stockholm, Sweden, (no 2018/ 2080-31/1) and the Regional Committee for Ethics in Medical Research (no. 2018/939) in Norway. Furthermore, the study was conducted in accordance with the Helsinki Declaration and as an observational study in accordance with international accepted STROBE guidelines [26].

\section{Results}

\section{Basic characteristics}

In Sweden, 3529 individuals receiving OAT were identified. Around $70 \%$ were male, with a mean age of approximately 44 years and 45 years in 2014 and 2017, respectively. See additional file 5 . The majority of the 
OAT patients were treated with buprenorphine-based OAT medication (52\% in 2014 and 56\% in 2017). Altogether 407 individuals in the Swedish cohort received $\mathrm{HCV}$ treatment during the study period. In Norway, 7739 individuals were identified during the study period from 2014 to 2017. $70 \%$ were male and mean age was 44 in 2014 and almost 46 years in 2017. $55 \%$ received treatment with a buprenorphine-based OAT medication in 2017. Altogether 920 individuals in the Norwegian cohort received HCV treatment during the study period (Table 1).

\section{Estimated HCV prevalence and treatment uptake}

For Sweden, chronic HCV prevalence was estimated to range from $55.6 \%$ (uncertainty interval (UI) 53.3 to 58.8 ) in 2014, to 53.1 (UI: 50.8-56.3) in 2017. In Norway, prevalence was estimated from 54.4 (UI: 52.1-57.5) in 2014 to 50.0 (UI: 47.7-53.1) in 2017. The cumulative $\mathrm{HCV}$ treatment uptake was thus projected to be $31 \%$ in Norway and $28 \%$ in Sweden for the study period (Table 2). Unadjusted treatment rates for both countries are shown in additional file 6, (Fig. 1).

\section{Dispensations and predictors of DAA treatment in 2017}

OAT patients in Norway and Sweden were stratified according to whether they received DAA treatment or not,

Table 1 Basic characteristics of patients receiving OAT in 2014 and 2017 in Sweden and Norway

\begin{tabular}{|c|c|c|c|c|}
\hline \multirow[b]{2}{*}{ Country } & \multicolumn{2}{|l|}{2014} & \multicolumn{2}{|l|}{2017} \\
\hline & Sweden & Norway & Sweden & Norway \\
\hline OAT studypopulation, $\mathrm{n}$ & 2663 & 6057 & 2739 & 5545 \\
\hline \multicolumn{5}{|l|}{ Gender, n (\%) } \\
\hline Male & $1911(72)$ & $4266(70)$ & $1961(72)$ & $3870(70)$ \\
\hline Female & $752(28)$ & $1791(30)$ & $778(28)$ & $1675(30)$ \\
\hline \multicolumn{5}{|l|}{ Age, n (\%) } \\
\hline $18-35$ & $671(25)$ & $1219(20)$ & $647(24)$ & $878(16)$ \\
\hline $36-45$ & $817(31)$ & $2181(36)$ & $819(30)$ & $1747(32)$ \\
\hline $46-55$ & $744(28)$ & 2044 (34) & $713(26)$ & $1998(36)$ \\
\hline $56-75$ & $431(16)$ & $613(10)$ & $560(20)$ & $922(17)$ \\
\hline \multicolumn{5}{|l|}{ Mean age (SD) } \\
\hline Male & $44(10)$ & $44.1(9)$ & $45.1(11)$ & $46.1(9)$ \\
\hline Female & $43.5(11)$ & $43.1(9)$ & $44.3(12)$ & $45.2(10)$ \\
\hline \multicolumn{5}{|l|}{ OAT medication, $\mathrm{n}(\%)^{\mathrm{a}}$} \\
\hline $\begin{array}{l}\text { Methadone/ } \\
\text { levomethadone }\end{array}$ & $1267(48)$ & $2810(46)$ & $1198(44)$ & $2504(45)$ \\
\hline Buprenorphine & $875(33)$ & 2049 (34) & 1075 (39) & $2190(40)$ \\
\hline Buprenorphine/naloxone & $521(20)$ & $1198(20)$ & $466(17)$ & $851(15)$ \\
\hline
\end{tabular}

Sources: The Swedish Prescribed Drug Register (SPDR), The Norwegian

Prescription Database (NorPD)

OAT Opioid agonist therapy, SD Standard deviation

aLast registered OAT medication each calendar year and compared in 2017. In the Norwegian cohort 366 individuals (6.6\%) received DAA treatment whereas in Sweden, 123 (4.5\%) individuals received treatment. Variations in treatment within countries were few, except for drugs used for diabetes (Table 3). However, among individuals receiving DAA treatment in Norway, half were also dispensed benzodiazepines compared to only $15 \%$ in Sweden. In contrast, 24 and $31 \%$ of the Swedish patients treated with DAA also received dispensations of $\mathrm{z}$ hypnotics and antidepressants compared to 15 and $20 \%$ in the Norwegian cohort, respectively.

In a logistic regression model (additional file 7), DAA treatment was associated with increased age (adjusted odds ratio (aOR) 1.8; 95\% CI 1.0-3.2) and dispensation of drugs used in diabetes (aOR 3.2; 95\% CI 1.8-5.7) in Sweden. Dispensations of lipid modifying agents and antibacterials were associated with decreased odds (aOR 0.4; 95\% CI 0.2-0.9, aOR 0.8; 95\% CI 0.6-1.0) of receiving DAA treatment in Norway. Moreover, being female was associated with decreased odds in both countries (S: aOR 0.6; 95\% CI 0.3-0.9, N: aOR 0.8; 95\% CI 0.6-1.0).

\section{Discussion}

Amid the hepatitis $\mathrm{C}$ endemic among PWIDs and individuals enrolled in OAT programs in Sweden and Norway, the study has revealed a large increase in DAA treatment uptake among OAT patients in both countries from 2014 to 2017. As such, our findings reflect the immense progress, which has been achieved in HCV treatment during the recent years with almost a complete shift from interferon-based treatment to solely treatment with DAAs among OAT patients. The cumulative frequency of $\mathrm{HCV}$ treatment in the OAT population between 2014 and 2017 was estimated to be 28 and 31\%\% in Sweden and Norway, respectively.

Despite substantial increase in HCV treatment uptake in advanced health systems like Sweden and Norway, as found in our study, the treatment uptake is still too low and progress too slow globally $[20,28,29]$. Treatment demand has soared after the introduction of DAAs, especially among former PWIDs [11], while people who are still using drugs actively have seemingly not been fully able to benefit from the increased accessibility [11]. In order to reach universal health coverage of DAAs and elimination of $\mathrm{HCV}$, more efforts are needed in countries. Coverage of DAAs varied substantially across European countries, ranging from 0.6 to $10.2 \%$ in 2015 [30]. Restrictions in DAA access policies may explain these variations. Among European countries, England, Hungary, Croatia and Slovakia experienced one of the most restricted access policies to DAA treatment compared to Poland, Ireland, the Netherlands, France and Germany, which had the least restrictions during the study period [31]. Our findings saw Sweden with a greater DAA treatment uptake than Norway in 2015, and roughly in the 


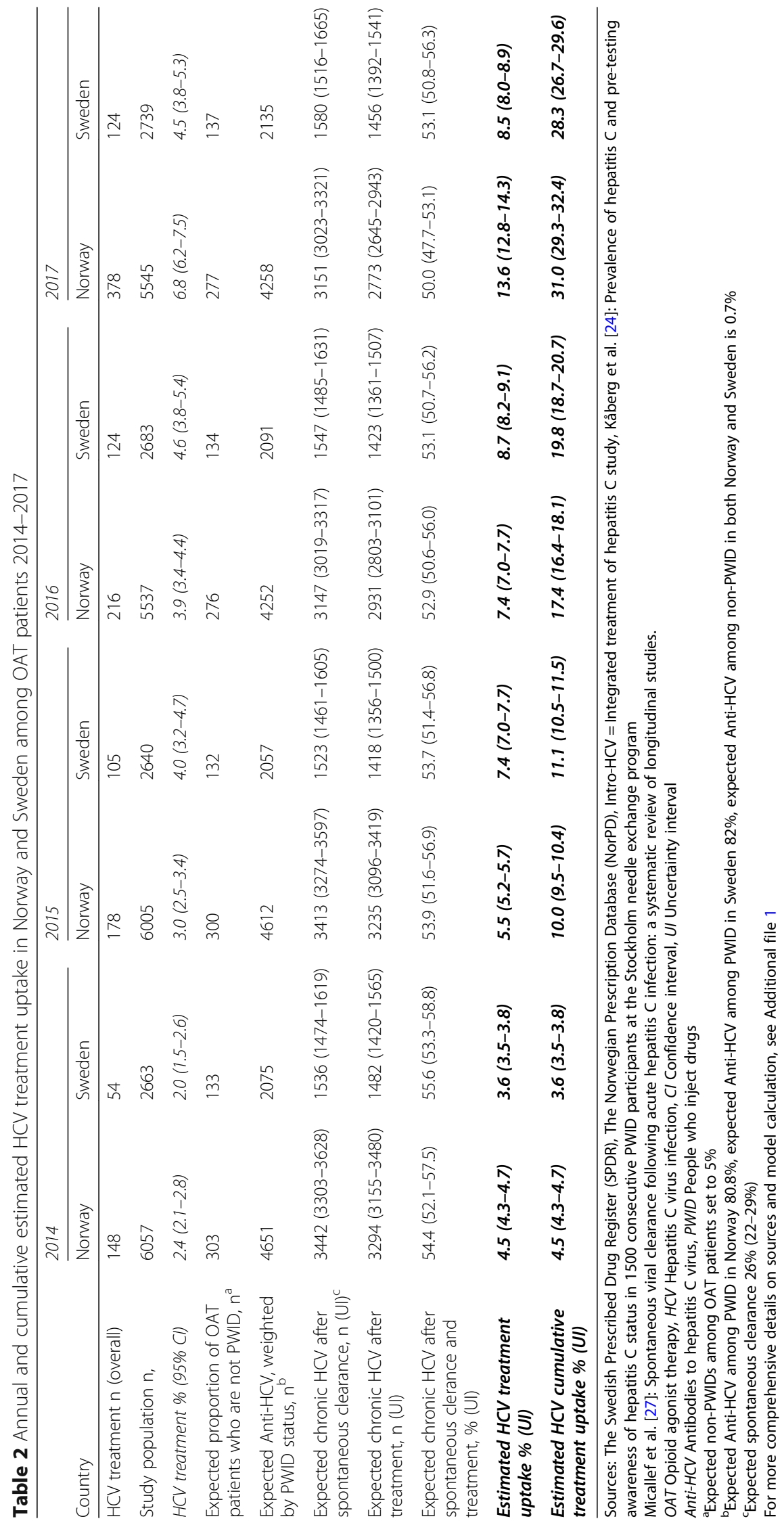



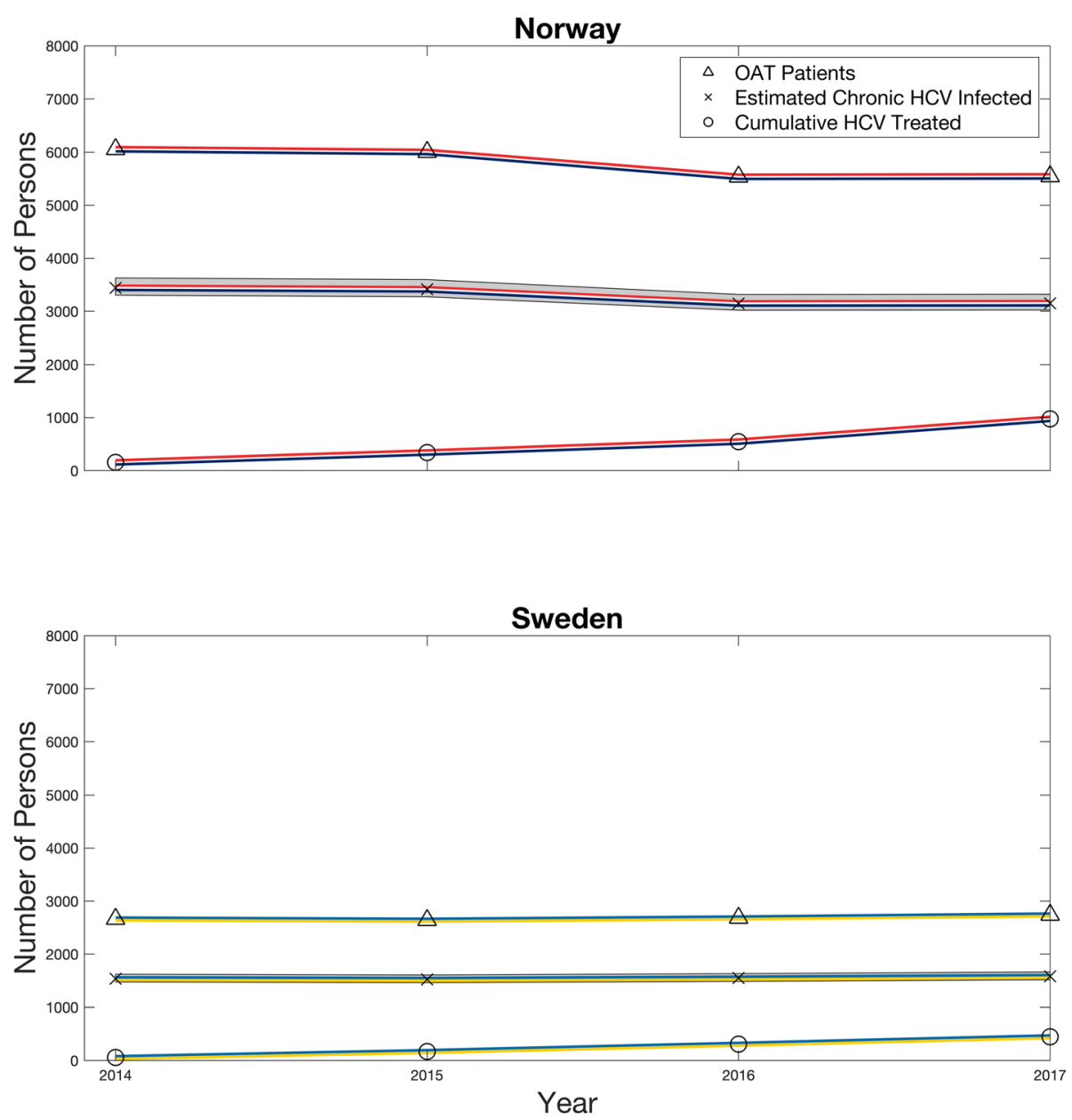

Fig. 1 Estimated HCV treatment uptake in Norway and Sweden among OAT patients from 2014 to 2017. HCV = hepatitis C virus infection, OAT= opioid agonist therapy. Sources OAT and HCV treatment: The Swedish Prescribed Drug Register (SPDR), The Norwegian Prescription Database (NorPD). Prevalence: Intro-HCV = Integrated treatment of hepatitis C study, Kåberg et al. [24]: Prevalence of hepatitis $C$ and pre-testing awareness of hepatitis C status in 1500 consecutive PWID participants at the Stockholm needle exchange program, Micallef et al. [27]: Spontaneous viral clearance following acute hepatitis C infection: a systematic review of longitudinal studies. For more comprehensive details on sources and model calculation, see additional file 1.

middle among its European counterparts, similar to the last Scandinavian country, Denmark, at close to 4\% [30]. Another reason for the low treatment uptake might be concerns about treatment compliance among PWIDs and OAT patients; however, this seems unwarranted as both good adherence and high SVR rates in this group have been documented in several randomized controlled trials [32, 33].

Arguably, poor treatment uptake of DAAs globally and a hard to reach population opts for countries to consider alternative health service delivery platforms. Addressing barriers to $\mathrm{HCV}$ treatment and testing are important. Between 60 and $70 \%$ of people enrolled in various opioid treatment programs are offered onsite testing for $\mathrm{HCV}$ [29], which is too low. OAT programs could thus benefit from introducing universal HCV testing and linkage to care in OAT settings. Perhaps OAT programs, together with infectious disease and gastroenterology/hepatology specialists, could explore any opportunities for non-specialists to dispense DAA regimens to increase treatment uptake. Psychoeducation to improve knowledge among OAT patients regarding treatment, possible side effects and HCV infection seems to improve both SVR rates and adherence to treatment and should also be considered implemented in an OAT setting [34]. Furthermore, current drug use or any fear of reinfection in patients already treated for HCV should not hinder treatment with DAA. Reinfections seems to be low (1-5\%), even if treated patients return to active drug use [35].

The differences between Sweden and Norway are interesting and relevant for other settings. Prevalence of anti-HCV among PWIDs seems consistently higher in Sweden compared to Norway $[36,37]$. Coverage of OAT is higher in Norway than Sweden. Waal et al. estimate an overall OAT coverage of around $60 \%$ among people 
Table 3 Dispensed drugs to patients receiving OAT and OAT/DAAs in Norway and Sweden in 2017

\begin{tabular}{|c|c|c|c|c|}
\hline \multirow{2}{*}{$\begin{array}{l}\text { Year } \\
\text { Country }\end{array}$} & \multicolumn{2}{|l|}{2017} & \multicolumn{2}{|l|}{2017} \\
\hline & Norway & & Sweden & \\
\hline \multirow[t]{3}{*}{ OAT study population, $\mathrm{n}$} & 5543 & & 2739 & \\
\hline & Only OAT & $\mathrm{DAA}+\mathrm{OAT}$ & Only OAT & $\mathrm{DAA}+\mathrm{OAT}$ \\
\hline & 5177 & 366 & 2616 & 123 \\
\hline Drugs & No. (\%) & No. (\%) & No. (\%) & No. (\%) \\
\hline Drugs used in Diabetes & $197(4)$ & $14(4)$ & $161(6)$ & $18(15)$ \\
\hline Antithrombotic agents & $529(10)$ & $35(10)$ & $217(8)$ & $8(7)$ \\
\hline Cardiovascular system drugs ${ }^{a}$ & $842(16)$ & $67(18)$ & $622(24)$ & $37(30)$ \\
\hline Lipid modifying agents & $271(5)$ & $10(3)$ & $121(5)$ & $4(3)$ \\
\hline Sex hormones and modulators of genital system & $654(13)$ & $51(14)$ & $430(16)$ & $14(11)$ \\
\hline Antibacterials for systemic use & $1901(36)$ & $112(31)$ & $915(35)$ & $33(27)$ \\
\hline Anti-inflammatory and ant-rheumatic products & $1155(22)$ & $69(19)$ & $570(22)$ & $25(20)$ \\
\hline Drugs for obstructive airway diseases & $1048(20)$ & $68(19)$ & $410(16)$ & $14(11)$ \\
\hline Benzodiazepines $^{\mathrm{b}}$ & $2368(46)$ & $181(50)$ & $402(15)$ & $19(15)$ \\
\hline Hypnotics and sedatives $^{c}$ & $797(15)$ & $54(15)$ & $691(26)$ & $30(24)$ \\
\hline Antiepileptics $^{d}$ & $823(16)$ & $57(16)$ & $629(24)$ & $25(20)$ \\
\hline Antidepressants ${ }^{\mathrm{e}}$ & $960(19)$ & $73(20)$ & $1008(39)$ & $38(31)$ \\
\hline Antipsychotics ${ }^{f}$ & $1401(27)$ & $85(23)$ & $602(23)$ & $28(23)$ \\
\hline
\end{tabular}

Source: The Swedish Prescribed Drug Register (SPDR), The Norwegian Prescription Database (NorPD). All drugs on ATC Level 2, except under Nervous system. See Supplement Table S2

OAT Opioid agonist therapy, DAA Direct-acting antiviral agents

${ }^{\mathrm{a}} \mathrm{C01}, \mathrm{C} 02, \mathrm{CO}, \mathrm{C07}, \mathrm{C} 08, \mathrm{C} 09$

${ }^{b} \mathrm{~N} 05 \mathrm{BA} 01, \mathrm{~N} 05 \mathrm{BA} 04, \mathrm{~N} 05 \mathrm{BA06}$, N05BA12, N05CD02, N05CD03, N05CD08, N03AE01

${ }^{\mathrm{N}} \mathrm{N} 05 \mathrm{CF} 01$ and N05CF02

${ }^{\mathrm{d}} \mathrm{N} 03 \mathrm{AA}, \mathrm{N} 03 \mathrm{AB}, \mathrm{N} 03 \mathrm{AF}, \mathrm{N} 03 \mathrm{AG}, \mathrm{N} 03 \mathrm{AX}$

N06AA, N06AB, N06AF, N06AG, N06AX

fN05AA, N05AB, N05AC, N05AD, N05AE, N05AF, N05AG, N05AH, N05AL, N05AN, N05AX

with opioid dependence in Norway [38] compared to 10 to $50 \%$ OAT coverage in Sweden [39]. Differences in OAT eligibility criteria could explain lower coverage of OAT in Sweden as compared to Norway. Norway altered its OAT guidelines in 2010, making opioid addiction the absolute criteria for inclusion and being retained in treatment, and there is a high threshold for discharging patients from OAT. However in Sweden, current OAT guideline has lower thresholds for OAT cessation in the case of repeated illicit drug use [7, 40]. The two populations may therefore be different and Swedish OAT patients could have less ongoing drug use, which could lower the risk of HCV and increase the chance for HCV treatment success. However, the Norwegian strategy could be more effective at a population level since hard to reach groups are included and illicit drug use is not considered as an exclusion criterion for OAT.

With the provision of DAA treatment available for all Swedish and Norwegian patients, it may be tempting to argue that this is the beginning of the end for the $\mathrm{HCV}$ endemic. In addition to OAT, maintaining a high coverage of needle and syringe availability in these countries, together with continued scale-up of DAA treatment, it may be possible to reduce incidence by $90 \%$ by 2030 as shown in a modeling study from the UK [41]. On the other hand it may still seem embryonic as there may be shortcomings in current $\mathrm{HCV}$ surveillance systems. $\mathrm{HCV}$ has been notified to The Norwegian Surveillance System for Communicable Diseases since 1990, yet, there has been no distinction between anti-HCV, HCV RNA or HCV core antigen reporting before 2016 [20]. Hence, accurate $\mathrm{HCV}$ prevalence and incidence data prior to 2016 are not readily available. Furthermore, in order to eliminate $\mathrm{HCV}$ as a public health threat by 2030, which both countries have embraced, a coherent and structured national plan is essential. The Norwegian Health Ministry introduced a national hepatitis C strategy in 2016, and was later revised in 2018, which focuses on DAA treatment, HCV surveillance, and prevention, and aims to reduce HCV incidence by $90 \%$ within 2023 [42]. On the contrary, an ambitious national Swedish hepatitis C plan has not yet been established [43].

Our findings suggest few inter-country differences in dispensed drugs among those treated with DAAs and those not, except for drugs used for diabetes in the Swedish cohort, which was significantly higher and demonstrated a 
strong association with DAA treatment. Chronic HCV might be a risk factor for developing immune system disorders, heart disease and diabetes, especially diabetes type II as the viral infection may increase insulin resistance [44, 45]. This finding was not mirrored in the Norwegian cohort. Dispensed drugs can serve as a proxy for comorbidity and it is well-established that both somatic and especially mental illness are underdiagnosed and undertreated among individuals with substance use disorders [46]. This does not explain the vast differences we observed among dispensations of benzodiazepines, z-hypnotics, and antidepressants comparing Sweden and Norway. Older patients are more likely to have cirrhosis and longer $\mathrm{HCV}$ treatment courses compared to younger patients. A reason for the observed age difference may be that the younger patients are usually harder to reach due to an unstable life situation and drug abuse related behavior. Similarly, the analyses point toward women being less likely to be treated for HCV, however, this could be due to women being underrepresented in services.

\section{Strengths and limitations}

The national prescription registries capture large populations, and as such, provide researchers with precise and near complete databases. The main strength of this study is that it offers a large sample of OAT patients being treated for $\mathrm{HCV}$.

However, this study has several limitations. As the patients were included each calendar year with a dosage criteria, a patient who commenced treatment late or quit early during the year may not obtain sufficient exposure to be included in that particular year. Moreover, OAT treatment in Norway and Sweden is not uniform. Most individuals are dispensed OAT medications at pharmacies while others receive the drugs at OAT outpatient clinics, which means that those latter patients are not identified in this study. OAT and HCV treatment administered to hospitalized and institutionalized patients are also not recorded in the registries. In addition, DDD does not necessarily reflect the prescribed daily dose.

Furthermore, HCV treatment uptake data was not linked on an individual level to diagnosis codes of $\mathrm{HCV}$ according to International Statistical Classification of Diseases and Related Health Problems version 10 (ICD-10) or the International Classification of Primary Care (ICPC), rather, it was estimated from published reports and modelled where adequate data sources were missing. Thus, there is some uncertainty in the denominator of people with $\mathrm{HCV}$ in need of treatment. The predictors for DAA treatment were limited to the main dispensed drugs and sociodemographic variables and so did not fully acknowledge that there could be other vital reasons why access to DAAs would be limited in this group of patients.
Finally, PWID are a heterogeneous group of individuals, and one should be careful not to generalize OAT patients to include all PWIDs.

\section{Conclusion}

This study indicates a large scale-up in DAA treatment among Swedish and Norwegian OAT patients. Cumulative HCV treatment uptake was around onethird from 2014 to 2017 in both countries, attributed by a complete shift to DAA treatment regimens. Amidst a HCV endemic among PWIDs, it seems that two-thirds of OAT patients in need of treatment were untreated in the beginning of 2018. Coupled with the prospect of $\mathrm{HCV}$ elimination, there is a need for further scale-up of the most effective $\mathrm{HCV}$ treatment strategies, by identifying possible predictors of treatment and to establish more accurate surveillance systems in order to provide better care to this group of marginalized people.

\section{Supplementary information}

Supplementary information accompanies this paper at https://doi.org/10. 1186/s13011-020-00286-2.

\section{Additional file 1. Methodology description: estimating chronic hepatitis $C$ ( $\mathrm{HCV}$ ) prevalence among people on opioid agonist therapy (OAT) in Norway and Sweden:}

Additional file 2. Flowchart of study populations in Norway and Sweden from 2014 to 2017. According to World Health Organization Collaborating Centre for Drug Statistics Methodology, ATC/DDD Index. OAT= opioid agonist therapy, DDD = defined daily dose. The DDDs are the assumed average maintenance dose per day for a drug used for its main indication. *Therapeutic subgroup, chemical subgroup, or chemical substance. ${ }^{* *}$ Including clonazepam. ${ }^{* * *}$ Excluding clonazepam

Additional file 3. Opioid agonist therapy and hepatitis C treatment in Norway and Sweden

Additional file 4. Anatomical Therapeutic Chemical Classification and defined daily dose for OAT medications. OAT = opioid agonist therapy; SD = standard deviation; Sources: The Swedish Prescribed Drug Register (SPDR), The Norwegian Prescription Database (NorPD). *Last registered OAT medication each calendar year

Additional file 5. Basic characteristics of patients receiving OAT from 2014 to 2017 in Sweden and Norway. OAT = opioid agonist therapy, HCV = hepatitis $\mathrm{C}$ virus infection, DAA = direct-acting antiviral agent, $\mathrm{Cl}=$ confidence interval. Sources: The Swedish Prescribed Drug Register (SPDR), The Norwegian Prescription Database (NorPD). *Exluding Ribavirin (J05AP01)

Additional file 6. Annual and cumulative DAA and HCV treatment among patients receiving OAT from 2014 to 2017. OAT = opioid agonist therapy, DAA = direct-acting antiviral agent, $\mathrm{OR}=$ odds ratio, $\mathrm{aOR}=$ adjusted odds ratio, $\mathrm{Cl}=$ confidence interval. Source: The Norwegian Prescription Database (NorPD) and The Swedish Prescribed Drug Register (SPDR). *N05BA01, N05BA04, N05BA06, N05BA12, N05CD02, N05CD03, N05CD08, N03AE01. **N05CF01 and N05CF02. ***N03AA, N03AB, N03AF, N03AG, N03AX. ***N06AA, N06AB, N06AF, N06AG, N06AX. ****N05AA, N05AB, N05AC, N05AD, N05AE, N05AF, N05AG, N05AH, N05AL, N05AN, N05AX. For ATC codes see additional file 4

Additional file 7. Logistic regression on factors associated with DAA treatment among patients receiving OAT in 2017. OAT = opioid agonist therapy. Sources: The Swedish Prescribed Drug Register (SPDR) and the Norwegian Prescription Database (NorPD). *Methadone, levomethadone, buprenorphine and buprenorphine-naloxone 


\section{Abbreviations}

OAT: Opioid agonist therapy; DAA: Direct-acting antiviral agents; HCV: Hepatitis C virus; PWID: People who inject drugs; NorPD: The Norwegian Prescription Database; SPDR: Swedish Prescribed Drug Register; ATC: Anatomical Therapeutic Chemical classification system; DDD: Defined daily dose; Anti-HCV: Antibodies to the Hepatitis C virus; SVR: Sustained virologic response; INTRO-HCV: Integrated treatment of hepatitis C study

\section{Acknowledgements}

Christer Kleppe, the Data Protection Officer at Helse Bergen, for his valuable contribution in corresponding with data registry owners.

\section{Authors' contributions}

This observational study was led by CFA in terms of study design, analyzes, drafting and writing the article. All authors contributed to the conception, writing, and revising the draft(s) critically. All authors have read and approved the version to be published.

\section{Funding}

This study is part of the main INTRO-HCV study, which was funded by The Norwegian Research Council (no. 269855) and the Western Norway Regional Health Authority ("Åpen prosjektstøtte) with Department of Addiction Medicine, Haukeland University Hospital as responsible institution. The funders had no role in the study design, data collection and analyzes, decision to publish, nor preparation of any content in the manuscript. Two of the authors, CFA and JHV, are funded from the above research grant, whereas the other authors are funded by their respective affiliations.

\section{Availability of data and materials}

Supplemental tables, figure and data sources in this observational study are available in this published article and its additional files.

\section{Ethics approval and consent to participate}

The study was approved by the Regional Ethical Committee (no. 2018/939), Norway, on June 19, 2018 and by the Regional Ethical Review Committee in Stockholm (no 2018/2080-31/1), Sweden, on November 14, 2018. No informed consent from the participants was required.

\section{Consent for publication}

Not applicable.

\section{Competing interests}

I.O. is employed at the Centre for Pharmacoepidemiology, Karolinska Institutet, which receives grants from several entities (pharmaceutical companies, regulatory authorities, and contract research organizations) for performance of drug safety and drug utilization studies, unrelated to this work. None of the other authors have competing interests.

\section{Author details}

'Department of Addiction Medicine, Haukeland University Hospital, Bergen, Norway. ${ }^{2}$ Department of Global Public Health and Primary Care, University of Bergen, Bergen, Norway. ${ }^{3}$ The Norwegian Institute of Public Health (NIPH), Oslo, Norway. ${ }^{4}$ Institute for Clinical Medicine, University of Oslo, Oslo, Norway. ${ }^{5}$ Department of Medicine, Karolinska Institutet, Solna, Sweden. ${ }^{6}$ Population Health Sciences, Bristol Medical School, University of Bristol, Bristol, UK

\section{Received: 26 March 2020 Accepted: 23 June 2020}

\section{Published online: 30 June 2020}

\section{References}

1. Pecoraro V, Banzi R, Cariani E, Chester J, Villa E, D'Amico R, Bertele V, Trenti T. New direct-acting antivirals for the treatment of patients with Hepatitis $C$ virus infection: a systematic review of randomized controlled trials. J Clin Exp Hepatol. 2019:9(4):522-38.

2. Pearlman BL, Traub N. Sustained virologic response to antiviral therapy for chronic hepatitis C virus infection: a cure and so much more. Clin Infect Dis. 2011;52(7):889-900.

3. Manns MP, Buti M, Gane E, Pawlotsky JM, Razavi H, Terrault N, Younossi Z. Hepatitis C virus infection. Nat Rev Dis Primers. 2017;3:17006.
4. Aspinall EJ, Corson S, Doyle JS, Grebely J, Hutchinson SJ, Dore GJ, Goldberg DJ, Hellard ME. Treatment of hepatitis C virus infection among people who are actively injecting drugs: a systematic review and meta-analysis. Clin Infect Dis. 2013;57(Suppl 2):S80-9.

5. Nelson PK, Mathers BM, Cowie B, Hagan H, Des Jarlais D, Horyniak D, Degenhardt L. Global epidemiology of hepatitis $B$ and hepatitis $C$ in people who inject drugs: results of systematic reviews. Lancet (London, England). 2011;378(9791):571-83.

6. Degenhardt L, Peacock A, Colledge S, Leung J, Grebely J, Vickerman P, Stone J, Cunningham EB, Trickey A, Dumchev K, et al. Global prevalence of injecting drug use and sociodemographic characteristics and prevalence of HIV, HBV, and HCV in people who inject drugs: a multistage systematic review. Lancet Glob Health. 2017;5(12):e1192-207.

7. Waal HBK, Clausen T, Lillevold PH, Skeie I. SERAF Report: Status 2017. MAR 20 years. Status, evaluations and perspectives. In: The Norwegian Centre for Addiction Research (SERAF); 2018.

8. Meijerink H, White RA, Lovlie A, de Blasio BF, Dalgard O, Amundsen EJ, Melum E, Klovstad H. Modelling the burden of hepatitis C infection among people who inject drugs in Norway, 1973-2030. BMC Infect Dis. 2017;17(1):541.

9. Lagging M, Wejstal R, Duberg AS, Aleman S, Weiland O, Westin J. Treatment of hepatitis $C$ virus infection for adults and children: updated Swedish consensus guidelines 2017. Infect Dis (London, England). 2018;50(8):569-83.

10. The Norwegian Association of Infectious Diseases. Professional guidelines for diagnosing and treatment of Hepatitis $C$ among adults. In: The Norwegian Doctor Association (DNLF); 2019.

11. Hepatitis C - guidelines for health professionals. https://www.fhi.no/ nettpub/smittevernveilederen/sykdommer-a-a/hepatitt-c\%2D\%2D-veilederfor-helsepers/\#forekomst-i-norge. Accessed 3 Apr 2019.

12. Larney S, Peacock A, Leung J, Colledge S, Hickman M, Vickerman P, Grebely J, Dumchev KV, Griffiths P, Hines L, et al. Global, regional, and country-level coverage of interventions to prevent and manage HIV and hepatitis $C$ among people who inject drugs: a systematic review. Lancet Glob Health. 2017:5(12):e1208-20

13. Safreed-Harmon $\mathrm{K}$, Hetherington $\mathrm{KL}$, Aleman $\mathrm{S}$, Alho $\mathrm{H}$, Dalgard $\mathrm{O}$, Frisch $\mathrm{T}$, Gottfredsson M, Weis N, Lazarus JV. Policy responses to hepatitis C in the Nordic countries: gaps and discrepant reporting in the Hep-Nordic study. PLoS One. 2018;13(1):e0190146.

14. Platt L, Minozzi S, Reed J, Vickerman P, Hagan H, French C, Jordan A, Degenhardt L, Hope V, Hutchinson S, et al. Needle syringe programmes and opioid substitution therapy for preventing hepatitis $C$ transmission in people who inject drugs. Cochrane Database Syst Rev. 2017;9:Cd012021.

15. Hajarizadeh B, Cunningham EB, Reid H, Law M, Dore GJ, Grebely J. Directacting antiviral treatment for hepatitis $C$ among people who use or inject drugs: a systematic review and meta-analysis. Lancet Gastroenterol Hepatol. 2018;3(11):754-67.

16. Gowing L, Farrell MF, Bornemann R, Sullivan LE, Ali R. Oral substitution treatment of injecting opioid users for prevention of HIV infection. Cochrane Database Syst Rev. 2011. NO: 8 SN: 1465-1858.

17. Martin NK, Vickerman P, Foster GR, Hutchinson SJ, Goldberg DJ, Hickman M Can antiviral therapy for hepatitis $C$ reduce the prevalence of HCV among injecting drug user populations? A modeling analysis of its prevention utility. J Hepatol. 2011;54(6):1137-44.

18. Martin NK, Vickerman P, Grebely J, Hellard M, Hutchinson SJ, Lima VD, Foster GR, Dillon JF, Goldberg DJ, Dore GJ, et al. Hepatitis C virus treatment for prevention among people who inject drugs: Modeling treatment scale-up in the age of direct-acting antivirals. Hepatology (Baltimore, Md). 2013;58(5):1598-609.

19. Grebely J, Robaeys G, Bruggmann P, Aghemo A, Backmund M, Bruneau J, Byrne J, Dalgard O, Feld JJ, Hellard M, et al. Recommendations for the management of hepatitis $C$ virus infection among people who inject drugs. Int J Drug Policy. 2015;26(10):1028-38.

20. Midgard H, Bramness JG, Skurtveit S, Haukeland JW, Dalgard O. Hepatitis C treatment uptake among patients who have received opioid substitution treatment: a population-based study. PLoS One. 2016;11(11):e0166451.

21. Eide TB, Straand J, Björkelund C, Kosunen E, Thorgeirsson O, Vedsted P, Rosvold EO. Differences in medical services in Nordic general practice: a comparative survey from the QUALICOPC study. Scand J Prim Health Care. 2017;35(2):153-61

22. About the Norwegian Prescription Database. http://www.norpd.no/Niktig.aspx. Accessed 13 Mar 2019

23. Fadnes LT, Aas CF, Vold JH, Ohldieck C, Leiva RA, Chalabianloo F, Skurtveit S, Lygren OJ, Dalgard O, Vickerman $\mathrm{P}$, et al. Integrated treatment of hepatitis C 
virus infection among people who inject drugs: study protocol for a randomised controlled trial (INTRO-HCV). BMC Infect Dis. 2019;19(1):943.

24. Kaberg M, Hammarberg A, Lidman C, Weiland O. Prevalence of hepatitis C and pre-testing awareness of hepatitis $C$ status in 1500 consecutive PWID participants at the Stockholm needle exchange program. Infect Dis (London, England). 2017:49(10):728-36.

25. ATC Classification Index with DDDs 2018. https:/www.whocc.no/atc_ddd_index/. Accessed 18 Nov 2018.

26. Vandenbroucke JP, von Elm E, Altman DG, Gotzsche PC, Mulrow CD, Pocock SJ, Poole C, Schlesselman JJ, Egger M. Strengthening the Reporting of Observational Studies in Epidemiology (STROBE): explanation and elaboration. Int J Surg (London, England). 2014;12(12):1500-24.

27. Micallef JM, Kaldor JM, Dore GJ. Spontaneous viral clearance following acute hepatitis C infection: a systematic review of longitudinal studies. J Viral Hepat. 2006;13(1):34-41.

28. Alavi M, Raffa JD, Deans GD, Lai C, Krajden M, Dore GJ, Tyndall MW, Grebely J. Continued low uptake of treatment for hepatitis $C$ virus infection in a large community-based cohort of inner city residents. Liver Int. 2014;34(8): 1198-206.

29. Norton BL, Akiyama MJ, Zamor PJ, Litwin AH. Treatment of chronic Hepatitis $C$ in patients receiving opioid agonist therapy: a review of best practice. Infect Dis Clin N Am. 2018;32(2):347-70.

30. Papatheodoridis GV, Hatzakis A, Cholongitas E, Baptista-Leite R, Baskozos I, Chhatwal J, Colombo M, Cortez-Pinto H, Craxi A, Goldberg D, et al. Hepatitis C: the beginning of the end-key elements for successful European and national strategies to eliminate HCV in Europe. J Viral Hepat. 2018;25(Suppl 1):6-17.

31. Alcorn K: European HCV treatment access survey shows big variations in eligibility. AIDSmap. 2017.

32. Norton BL, Fleming J, Bachhuber MA, Steinman M, DeLuca J, Cunningham CO, Johnson N, Laraque F, Litwin AH. High HCV cure rates for people who use drugs treated with direct acting antiviral therapy at an urban primary care clinic. Int J Drug Policy. 2017;47:196-201.

33. Dore GJ, Altice F, Litwin AH, Dalgard O, Gane EJ, Shibolet O, Luetkemeyer A, Nahass R, Peng CY, Conway B, et al. Elbasvir-Grazoprevir to treat Hepatitis C virus infection in persons receiving opioid agonist therapy: a randomized trial. Ann Intern Med. 2016;165(9):625-34.

34. Reimer J, Schmidt CS, Schulte B, Gansefort D, Golz J, Gerken G, Scherbaum $N$, Verthein $U$, Backmund M. Psychoeducation improves hepatitis $C$ virus treatment during opioid substitution therapy: a controlled, prospective multicenter trial. Clin Infect Dis. 2013;57(Suppl 2):S97-104.

35. Grady BP, Schinkel J, Thomas XV, Dalgard O. Hepatitis C virus reinfection following treatment among people who use drugs. Clin Infect Dis. 2013; 57(Suppl 2):S105-10.

36. Han R, Zhou J, Francois C, Toumi M. Prevalence of hepatitis C infection among the general population and high-risk groups in the EU/EEA: a systematic review update. BMC Infect Dis. 2019;19(1):655.

37. European Centre for Disease Prevention and Control: Systematic review on hepatitis B and C prevalence in the EU/EEA. 2016.

38. Nilsen L. Færre nye rusmisbrukere inn i LAR. Oslo: Dagens Medisin; 2017.

39. World Health Organization: ATLAS of substance use disorders: resources for the prevention and treatment of substance use disorders (SUD). Country Profile: SWEDEN 2010.

40. European Monitoring Centre for Drugs and Drug Addiction: Sweden, Country Drug Report 2019. 2019.

41. Ward Z, Platt L, Sweeney S, Hope VD, Maher L, Hutchinson S, Palmateer N, Smith J, Craine N, Taylor A, et al. Impact of current and scaled-up levels of hepatitis C prevention and treatment interventions for people WHO inject drugs in three UK settings-what is required to achieve the WHO's HCV elimination targets? Addiction (Abingdon, England). 2018;113(9):1727-38,

42. Ministry of Health and Care Services. National strategy against hepatitis 2018-2023. In: Ministry of Health and Care Services; 2018.

43. Folkehälsomyndigheten: Hälsofrämjande och förebyggande arbete med hepatiter i Sverige - Kunskapsunderlag, analys och bedömningar. 2019.

44. Hammerstad SS, Grock SF, Lee HJ, Hasham A, Sundaram N, Tomer Y. Diabetes and Hepatitis C: a two-way association. Front Endocrinol. 2015;6:134.

45. Lee KK, Stelzle D, Bing R, Anwar M, Strachan F, Bashir S, Newby DE, Shah JS, Chung MH, Bloomfield GS, et al. Global burden of atherosclerotic cardiovascular disease in people with hepatitis $C$ virus infection: a systematic review, meta-analysis, and modelling study. Lancet Gastroenterol Hepatol. 2019;4(10):794-804.
46. European Monitoring Centre for Drugs and Drug Addiction: Komorbiditet — samförekomst av narkotikamissbruk och psykisk störning. Ett underskattat tillstånd. 2004

\section{Publisher's Note}

Springer Nature remains neutral with regard to jurisdictional claims in published maps and institutional affiliations.
Ready to submit your research? Choose BMC and benefit from:

- fast, convenient online submission

- thorough peer review by experienced researchers in your field

- rapid publication on acceptance

- support for research data, including large and complex data types

- gold Open Access which fosters wider collaboration and increased citations

- maximum visibility for your research: over $100 \mathrm{M}$ website views per year

At BMC, research is always in progress.

Learn more biomedcentral.com/submissions 